\title{
The Impact of Macroeconomic Factors on Banks Liquidity Risk: Evidence From Pakistan
}

\author{
Muhammad Yar Khan \\ Management Sciences, COMSATS University Islamabad \\ Wah Campus, Pakistan \\ muhammadyar@ciitwah.edu.pk \\ Javaria Liaqat \\ Management Sciences, COMSATS University Islamabad \\ Wah Campus, Pakistan \\ javairiajavairia@gmail.com \\ Tahira Awan \\ Management Sciences, International Islamic University Islamabad, Pakistan \\ tahira.awan@iiu.edu.pk \\ Wajid Khan \\ Management Sciences, Preston University Kohat, Pakistan \\ wajiduomm@gmail.com
}

\begin{abstract}
The aim of the study is to identify the factors that influence liquidity risks of the banks by considering the panel of 18 top listed banks in Pakistan during a period of $2010-2016$. The study employed panel random effect regression model to absorb time-invariant shocks, which gives robust inferences. The results of liquidity risk confirmed that the country's economic growth and price inflation further escalates liquidly risk while, FDI inflows reduces liquidity risks in Pakistani's banks, thus it is concluded that bank's liquidity risks required easy monetary policy to advancing loans and charging low interest rate, which ultimately will increase ROA, and ROE, while it would helpful to decrease high risk of bank's liquidly in a given country.
\end{abstract}

Keywords: Liquidity risk; Macroeconomic factors; Commercial banks; Pakistan

\section{Introduction}

In the past decades, banking system has become global and larger than they used to be, they have great importance in supporting economic growth of a country. A well-developed banking sector gives rise in quality services at low costs to businesses and common man as well. Economy having profitable banking sector have an efficiency to deal with the negative shocks and contributes to achieve a stable financial system. Banks are considered as the basic financial sector of any economy. Liquidity of banks is positively related with foreign direct investment, an increase in FDI, leads to increase in exports (Ferrouhi \& Lehadiri, 2013). Kirabaeva (2009)states that countries with less developed financial sectors face higher uncertainty regarding investment productivity, and a higher level of liquidity risk causes to attract capital formation in the form of FDI inflows. According to Goldberg (2009)performance of banking sector is affected by foreign 
direct investment. (Davydenko, 2010)stated that profitability of banks is affected by the CPI only in that way if expectations of inflation rate are fully anticipated or if the level of operating expenses and bank's wages increase in a faster manner as compare to the rate of inflation.

Following is the key objective of study,

i) To examine the impact of macroeconomic factors and financial indicators on liquidity risk.

Further this study will identify the main factors that have great impact on liquidity risk of the banks.

The real motivation of study is to identify the potential determinants of liquidity risks in a country. The liquidity risk is largely influenced by bank-specific factors including size of bank, deposits, ratio of capital and loans, andcountries macroeconomic factors. The study will propose a dynamic framework for measuring Liquidity risk, which will yield a conclusive finding which will highlight the new facts for enhanced understanding of liquidity risk and profitability of banks in emerging economy like Pakistan. There is a huge gap exist in the literature, where macroeconomic factors are invisible in measuring the liquidity risks ((Abdullah \& Khan, 2012; Akhtar, Ali, \& Sadaqat, 2011).

This study will fill the gap, missing in previous existing literature and includes i) large sample of banks, ii) sufficient time period, i.e., from 2010-2016, iii) 4 bank-specific factors, iv) 3 macroeconomic factors, v) and 2 financial indicators. We believe that this work is extended in a sufficient mode and it will provide a knowledgeable framework to analyze banking liquidity risk in a country.

\section{Literature Review and Hypothesis development}

In the current study, Literature review is divided the in to two sections. First section includes the theoretical framework and second section includes the empirical work.

\subsection{Theoretical Framework}

The theoretical framework of study is based on anticipated income theory, shift ability theory and financial intermediation theory. Anticipated income theory states that if the payment of loans is executed on time then the level of liquidity will rise. While, shift ability theory postulate that banks can insulate themselves against massive deposits withdrawals by holding, credit instruments for which there is a ready secondary market. This may decline chances of liquidity risk. Liquidity problems of banks including risk can be maintained through planning. It explained that the payment of loans and new deposits helps to maintain good level of liquidity. While lower level of deposits and loans causes to decline the level of liquidity and rises the problem of liquidity risk. So, loans and deposits are important factors that influence the level of liquidity.

\subsection{Empirical Framework}

Liquidity risk is analyzed in the connection where high liquidity risk influenced by bank-specific and country's macroeconomic factors. This discussion needs comprehensive survey of literature to analyze the previous findings, which will helpful to propose certain policy implications in the context of Pakistan.

\subsubsection{Determinants of liquidity risk}

A very limited literature is available on the linkage of foreign direct investment and bank's liquidity risk. In this regard, Fola (2015)examined the determinants of bank's liquidity in Ethiopia by macroeconomic and bank's specific factors for the period of 2011-2015 by taking 12 commercial banks. Foreign direct investment, real growth rate of GDP and consumer price index are used as industry specific factors; while banking factors measured by size of the bank, deposits 
and funding cost. Findings of the study reveal that macroeconomic variables has significant association with liquidity risk. Moreover, NBE-bill purchase and FDI, banks size and bank deposits have negative impact on bank's liquidity whereas GDP growth rate and consumer price index are positively related with liquidity of banks in Ethiopia. Elahi (2017)analyzed the liquidity risk of banks of UK and Germany. The study used the time frame of 2001 to 2012. Whereas data of the other variables used in study is collected from World Bank. This study used 11 variables which are foreign direct investment, size of banks, broad money supply M2, external funding to total liabilities, capital, gross domestic product, return on asset, financial crises and consumer price index. Empirical findings of the study indicated that foreign direct investment and consumer price index are positively correlated with liquidity of banks, further, broad money supply, size of banks, capital and foreign assets are also positively correlated with liquidity. On the other hand gross domestic product, return on asset, public deficit and financial crises are negatively correlated with liquidity of banks. However, unemployment rate and return on equity have no impact on liquidity of banks. This paper suggest that banks having large size have more liquidity than the banks having small size which indicates that size of banks has a great influence on liquidity.

Sheefeni and Nyambe (2016)examined the determinants of bank's liquidity risk in the scenario of Namibia. Error correction model and unit root bound test was used for analysis. Macroeconomic variables which are used in study are consumer price index, GDP and monetary policy measured in terms of broad money supply M2. Empirical findings revealed that gross domestic product is positively and significantly correlated with the liquidity risk, which means it is the basic determinant of liquidity(Khan et al., 2019). While, consumer price index rate has negative and statistically insignificant relationship with liquidity risk of commercial banks of Namibia. Moreover monetary policy which is measured in terms of broad money supply M2 has positive impact on liquidity risk of commercial banks but this impact is statistically insignificant. A very limited literature is available on the relationship of liquidity risk and broad money supply for instance; Damjanovic, Damjanovic, and Nolan (2017)examined the linkage between Bank Liquidity risk, broad money supply and credit risk and for United States before and after the financial crises. The study used the time span of 1990 to 2008. Broad money multiplier is taken as a measure of M2 broad money supply. Empirical findings of the study suggest that before financial crises there is a negative but significant relationship between broad money supply and risk(Khan, Awan, Saleem, \& Javeed, 2017). But after crises there was positive as well as significant relationship between broad money supply and risk free rate. Results also show that liquidity risk was positively and significantly associated with broad money supply before financial crises but after financial crises when liquidity risk was negatively and significantly associated with broad money supply. In other words when liquidity risk dominates broad money supply and risk had positive relationship with each other before crises. But after crises findings reveal that there exist a negative relation between broad money supply and liquidity risk. So, we formulate our twelfth, thirteenth and fourteenth hypothesis:

$\mathbf{H}_{1}$ : There is a positive and statistically significant relationship between liquidity risk and GDP.

$\mathbf{H}_{2}$ : There is a positive and significant association between liquidity risk and foreign direct investment.

$\mathbf{H}_{3}$ : Liquidity risk and consumer price index are positively and significantly associated. 


\section{Methodology}

\subsection{Data and Model Specification}

The study used the time series data set which covers a 7-year period from 2010 to 2016 with a sample of 18 banks of Pakistan. Data of bank specific factors including loans, capital ratio, deposits and bank size is collected from the published annual reports of banks, while data of macroeconomic factors (GDP, foreign direct investment, consumer price index) and financial development indicators ( market Capitalization, broad money supply)is obtained from WDI (world development indicators published by World Bank).

\subsection{Dependent Variable:}

Liquidity risk is used a dependent variable.Liquidity risk is that condition in which a bank or company fails to convert its assets in to cash without bearing a loss(Khan, Javeed, \& Khan, 2018). Or it is a condition when a bank becomes unable to meet short term financial demands, calculated as the ratio of capital to total assets (Boussanni, Desrochers, \& Préfontaine, 2008).

\subsection{Independent Macroeconomic Variables}

These are the external factors which influence the performance and liquidity risk of banks.

\subsubsection{Real GDP growth rate}

It is the sum of goods and services which are produced in a country within the period of one year. It is calculated as the ratio of GDP to population, this measure is used by many of the previous studies (Growe, DeBruine, Lee, \& Tudón Maldonado, 2014; Lee \& Kim, 2013).

\subsubsection{Consumer price index}

According to Nyoni (2019)there are so many indicators of inflation through which it can be measured and consumer price index is one of them. Consumer price index is an index that measures the changes in the price of goods and services which is always taken in the form of annual percentage. This proxy is used by many of the prior studies such as(Waemustafa \& Sukri, 2016).

\subsubsection{Foreign Direct investment}

FDI is an investment which is made by other countries in the host country. FDI is an important source of bringing higher profitability(Fola, 2015).

\subsection{Control variables}

Two financial development factors are used as control variables which are, market capitalization and broad money supply.

\subsubsection{Market capitalization}

It is company's total market value of outstanding shares. Market capitalization has some influence on liquidity risk and performance of banks. In this study is taken in terms of percentage of GDP. Some previous studies also use this measure such as (Gul, Irshad, \& Zaman, 2011).

\subsubsection{Broad Money Supply}

Broad money supply is the measure of country's money supply. Usually it supports the performance of banks and lowers the chances of liquidity risk(Waemustafa \& Sukri, 2016). It is measured in term of percentage of GDP. This measure is used by many of the previous studies such as (Sheefeni \& Nyambe, 2016).

\subsection{Model Specification}

The basic objective of the study is to analyze the impact of bank specific and macroeconomic factors on liquidity risk and profitability of banks. For this purpose the study estimated the following equations. 
$L R=\beta_{0}+\beta_{1} G D P+\beta_{2} F D I+\beta_{3} C P I+\beta_{4} M C+\beta_{5} M 2+\varepsilon$

Where,

LR Liquidity Risk

GDP Gross domestic product

FDI Foreign direct investment

CPI Consumer price index

MC Market capitalization

M2 Broad money supply

$\varepsilon \quad$ Error term

\section{Data Analysis and Results}

This section consists of the results of descriptive statistics, correlation matrix and panel random effect.

\subsection{Descriptive Analysis and correlation matrix}

Table 1shows the descriptive statistic of the variables. Consumer price index and gross domestic product has a mean value of 4.496 and 608.04 respectively, while foreign direct investment as percentage of GDP shows a maximum value of 1.139 with a mean value of 0.390 with the standard deviation value of 0.388 , it is positively skewed at a high kurtosis value.

Table 1: Descriptive Statistics

\begin{tabular}{|c|c|c|c|c|c|}
\hline & $\begin{array}{l}\text { FDI } \\
\text { (\%of } \\
\text { GDP) }\end{array}$ & GDP & LR & $\begin{array}{r}\text { M2 } \\
(\%)\end{array}$ & $\begin{array}{c}\text { MKAPT } \\
(\% \text { of GDP })\end{array}$ \\
\hline Mean & 0.390216 & 608.0400 & 0.018218 & 7.557131 & 10.57950 \\
\hline Maximum & 1.139753 & 1178.798 & 0.120265 & 17.39502 & 21.42374 \\
\hline Std. Dev. & 0.388063 & 547.1895 & 0.031397 & 6.918519 & 9.622138 \\
\hline Skewness & 0.351241 & -0.210537 & 2.136802 & -0.101001 & -0.151878 \\
\hline Kurtosis & 1.811831 & 1.062218 & 6.323127 & 1.191396 & 1.106486 \\
\hline Observations & 126 & 126 & 126 & 126 & 126 \\
\hline
\end{tabular}


Financial development indicators including broad money supply as percentage and market capitalization as percentage of GDP shows a mean value of 7.55 and 10.57 respectively. Liquidity risk represent mean value of 0.018 with maximum value of 0.120 with standard deviation value of 0.188 , the variable is positively skewed distribution at a high kurtosis value. These values are in line with the literature (Khan, 2016; Khan, Awan, et al., 2017).

Table 2: Correlation Matrix

\begin{tabular}{llllll}
\hline & FDI & GDPPC & LR & M2 & MKAPT \\
FDI & 1.000000 & & & & \\
GDPPC & 0.090928 & 1.000000 & & & \\
LR & 0.474392 & 0.514523 & 1.000000 & & \\
M2 & 0.086690 & 0.093960 & 0.514491 & 1.000000 & \\
MKAPT & 0.092051 & 0.098625 & 0.512836 & 0.096913 & 1.000000
\end{tabular}

Table 2 shows correlation matrix. The results show that the relationship of bank specific factors, macroeconomic factors and financial development indicators with liquidity risk is positive and significant which means that these all factors substantially increases liquidity risk in a country. The values are consistent with the past studies (Anam, Sany Sanuri, \& Ismail, 2018; Ibrahim, Awan, \& Khan, 2018; Khan, Al Bassam, Khan, \& Javeed, 2017)

\subsection{Hausman Test}

Before going to estimate panel regression model, we discriminate panel fixed model effect with the panel random model effect by Hausman test. Table 3 shows Hausman test for model specification for macroeconomic and financial development indicators.

\section{Table 3: Hausman test}

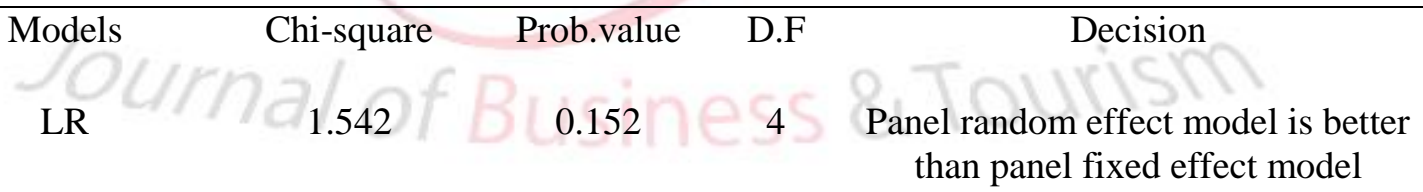

The Hausman test clearly indicates that the chi-square values insignificant at 5\% confidence interval. Hence, we may conclude that panel random effect model is better suited as compare to panel fixed effect model. Where we see the magnitude and direction of the variables.

\subsection{Pannel Random Effect Model}

Following the suggestions ofHausman test, panel random effect regression has been used in this study to analyze the relationship between macroeconomic factors and liquidity risk of Pakistani Banks.

Table 4: Panel Random Effect Regression

Liquidity risk (dependent variable)

\begin{tabular}{|c|c|c|c|c|}
\hline Variable & Coefficient & Std. Error & t-Statistic & Prob. \\
\hline $\mathrm{C}$ & 0.002898 & 0.009701 & 0.298779 & 0.7656 \\
\hline GDPPC & $2.36 \mathrm{E}-05$ & $1.23 \mathrm{E}-05$ & 1.928140 & 0.0562 \\
\hline CPI & 0.001400 & 0.000252 & 5.565291 & 0.0000 \\
\hline M2 & -0.000703 & 0.000427 & -1.646953 & 0.1022 \\
\hline $\mathrm{MC}$ & 0.000271 & 0.000350 & 0.774919 & 0.4399 \\
\hline
\end{tabular}




\begin{tabular}{lr} 
FDI & -0.007418 \\
\hline \hline R-squared & 0.275733 \\
Adjusted R-squared & 0.245555 \\
F-statistic & 9.136947 \\
Prob(F-statistic) & 0.000000
\end{tabular}

Table 4 shows the impact of macroeconomic variables and financial development factors on liquidity risk. The results show that gross domestic product and CPI has positive and significant impact on liquidity risk. Which indicates that increase in level of consumer price index and gross domestic product leads to increase the level of liquidity risk. The results are in line with the previous literature(Chen, Shen, Kao, \& Yeh, 2018; Elahi, 2017; Fola, 2015; Ghenimi, Chaibi, \& Omri, 2017; Rao \& Jirra, 2017; Sheefeni \& Nyambe, 2016). So, our twelfth and fourteenth hypothesis are accepted. Moreover, FDI has negative but significant impact on liquidity risk which means increase in the level of foreign direct investment substantially declines the level of liquidity risk. The results are linked with the previous studies (Javed \& Khan, 2011; Rao \& Jirra, 2017). Findings are unexpected so our thirteenth hypothesis is rejected. Further, broad money supply and market capitalization are unable to significantly explain liquidity risk. Here our twelfth and fourteenth hypothesis is accepted while, thirteenth hypothesis is rejected. Other statistics shows that around $30 \%$ of the macroeconomic factors explained the dependent variable. Further model is stable over a period of time which is visible by the p-value of F-statistics, it also shows $99.9 \%$ confidence interval.

\section{Conclusion and recommendations}

\subsection{Conclusion}

The study focused on the dynamic linkages between macroeconomic factors and liquidity risks by using a longitudinal data set of 18 banks in Pakistan during a period of 2010-2016. The study discussed the model is related with liquidity risk and macroeconomic factors. The results show that liquidly risk is influenced by country's per capita income, FDI inflows, and price inflation. Thus, the string capital market is required to regulate bank-specific factors to helpful to increase bank's specific measures and reduce liquidity risk. The central bank of a country should have to adopt easy monetary policy in order to increase advancing loans and charging less interest rate, which ultimately would helpful to increase ROA and ROE, while it would decrease the risk of liquidity in a banks.

\subsection{Policy implications}

The results have important policy implications. In the case of liquidity risk, banks must increase their size to avoid the problem of liquidity risk. As results show that banks with the bigger size face less risk. Banks having small size face higher level of liquidity risk. So, banks are invited to well manage their risk by reinforcing their own resources.

\subsection{Suggestions for Future Research}

Liquidity risk and macroeconomic factors analysis is a worthwhile study, it engages many areas of research. So, it is better to explore the following areas e.g., Financial deepening and banking activities, liquidity risk and profitability of Islamic banks, Management of liquidity risk. Moreover, as current study is conducted for Pakistan, it can also be conducted in the context of developed countries. This study used the sample of 18 banks, the future researchers can increase the sample size and time period. 


\section{References}

Abdullah, A., \& Khan, A. Q. (2012). Liquidity risk management: a comparative study between domestic and foreign banks in Pakistan. Journal of Managerial Science, 6(1), 62-72.

Akhtar, M. F., Ali, K., \& Sadaqat, S. (2011). Liquidity risk management: a comparative study between conventional and Islamic banks of Pakistan. Interdisciplinary journal of research in business, 1(1), 35-44.

Anam, J., Sanuri, S. B. M. M., \& Ismail, B. L. O. (2018). Conceptualizing the relation between halal logo, perceived product quality and the role of consumer knowledge. Journal of Islamic Marketing, 9(4), 727-746.

Boussanni, A., Desrochers, J., \& Préfontaine, J. (2008). Liquidity risk financial disclosure: the case of large European financial groups. International Business \& Economics Research Journal, 7(7), 47-56.

Chen, Y.-K., Shen, C.-H., Kao, L., \& Yeh, C.-Y. (2018). Bank liquidity risk and performance. Review of Pacific Basin Financial Markets and Policies, $21(01), 1850007$.

Damjanovic, T., Damjanovic, V., \& Nolan, C. (2017). Liquidity Risk, Credit Risk and the Money Multiplier. Retrieved from

Davydenko, A. (2010). Determinants of bank profitability in Ukraine. Undergraduate Economic Review, 7(1), 2.

Elahi, M. (2017). Factors Influencing Liquidity in Leading Banks: A Comparative Study of Banks Operating in UK and Germany Listed on LSE. Imperial Journal of Interdisciplinary Research (IJIR), 3(2), 1557-1575.

Ferrouhi, E. M., \& Lehadiri, A. (2013). Liquidity determinants of moroccan banking industry.

Fola, B. (2015). Factors affecting liquidity of selected commercial banks in Ethiopia. PhD thesis, Addis Ababa University, Addis Ababa.[Google Scholar].

Ghenimi, A., Chaibi, H., \& Omri, M. A. B. (2017). The effects of liquidity risk and credit risk on bank stability: Evidence from the MENA region. Borsa Istanbul Review, 17(4), 238-248.

Goldberg, L. S. (2009). Understanding banking sector globalization. IMF Staff Papers, 56(1), 171-197.

Growe, G., DeBruine, M., Lee, J. Y., \& Maldonado, T. J. F. (2014). The profitability and performance measurement of US regional banks using the predictive focus of the "fundamental analysis research" Advances in management accounting (pp. 189-237): Emerald Group Publishing Limited.

Gul, S., Irshad, F., \& Zaman, K. (2011). Factors Affecting Bank Profitability in Pakistan. Romanian Economic Journal, 14(39).

Ibrahim, A., Awan, T., \& Khan, M. Y. (2018). Empirical investigation of socially responsible investments in Pakistani firms using Carhart Four Factor model. Business Review, 13(2), 51-80.

Javed, T., \& Khan, M. Y. (2011). Impact of Size and Risk Management on Economic Performance of Multinational Corporations. International Journal of Business and Social Science, 2(2).

Khan, M. Y. (2016). Corporate governance and cost of capital: evidence from Pakistani listed firms. University of Glasgow.

Khan, M. Y., Al Bassam, W. M. H., Khan, W., \& Javeed, A. (2017). Dividend Policy and Share Price Volatility "Evidence from Karachi Stock Exchange". 
Khan, M. Y., Awan, T., Saleem, N., \& Javeed, A. (2017). The Impact of Islamic Governance Mechanisms on Corporate Governance Compliance and Disclosure. Journal of Managerial Sciences, 11(3), 399-414.

Khan, M. Y., Javeed, A., Khan, M. J., Din, S. U., Khurshid, A., \& Noor, U. (2019). Political Participation Through Social Media: Comparison of Pakistani and Malaysian Youth. IEEE Access, 7, 35532-35543.

Khan, M. Y., Javeed, A., \& Khan, W. (2018). Capital Structure Determinants of Islamic and Conventional Banks of Pakistan. Sarhad Journal of Management Sciences, 4(2), 260-270.

Kirabaeva, K. (2009). International capital flows and liquidity crises. Bank of Canada.

Lee, J. Y., \& Kim, D. (2013). Bank performance and its determinants in Korea. Japan and the World Economy, 27, 83-94.

Nyoni, T. (2019). Time series modeling and forecasting of the consumer price index in Belgium. Rao, K. S., \& Jirra, T. D. (2017). Corporate governance, diversification, and risk management in commercial banks of Ethiopia. Corporate governance, 3(2).

Sheefeni, J., \& Nyambe, J. M. (2016). Macroeconomic Determinants of Commercial Banks'liquidity in Namibia. European Journal of Business, Economics and Accountancy, 4(5), 19-30.

Waemustafa, W., \& Sukri, S. (2016). Systematic and unsystematic risk determinants of liquidity risk between Islamic and conventional banks. 